Polymer Journal, Vol. 39, No. 2, pp. 129-137 (2007)

(C) 2006 The Society of Polymer Science, Japan

\title{
Photosensitive Polyesterimides Based on Reaction Development Patterning
}

\author{
Shintaro SUgAwARA, Masao TOMOI, and Toshiyuki OYAMA ${ }^{\dagger}$ \\ Department of Advanced Materials Chemistry, Faculty of Engineering, Yokohama National University, \\ 79-5 Tokiwadai, Hodogaya-ku, Yokohama 240-8501, Japan
}

(Received August 10, 2006; Accepted October 30, 2006; Published December 21, 2006)

\begin{abstract}
Various soluble polyesterimides with ketone or sulfone group in main chain were prepared by a direct one-pot polycondensation of the corresponding dianhydrides and diamines in the presence of $\gamma$-valerolactone/ pyridine catalyst. The polyesterimide films containing the photosensitive agent, diazonaphthoquinone compound PC- $5^{\circledR}$, gave positive patterns based on reaction development patterning (RDP) by UV irradiation and the following development with ethanolamine/NMP $/ \mathrm{H}_{2} \mathrm{O}$ mixture. The relationship between the main chain structure and photosensitivity such as shape of the resulting patterns and development time was examined, and the development time dramatically decreased by marginal introduction of electron-withdrawing group in the polymer and then gradually decreased with increasing its content. The scanning electron microscopic photograph showed that the shape of the resultant patterns depended on the polymer structure. [doi:10.1295/polymj.PJ2006093]

KEY WORDS Polyesterimide (PEsI) / Photoresist / Diazonaphthoquinone (DNQ) / Reaction Development Patterning (RDP) /
\end{abstract}

Photosensitive polymers, so-called photoresists, have been widely used in the field of microelectronics. ${ }^{1}$ In particular, positive photoresists of cresol novolac resin/diazonaphthoquinone (DNQ) systems as dissolution inhibition type have contributed to the progress of microlithography of semiconductor technology because of their high sensitivity, high resolution, and good resistance to dry-etching. ${ }^{2}$ In addition, chemically amplified resist systems based on photoacid generators and functionalized polymers such as polystyrene containing tert-butoxycarbonyl group have also been studied for further improvement of sensitivity and resolution. ${ }^{3}$ However, the development processes of these resist systems involve only dissolution of the polymers and/or simple reactions such as acid-base reaction, and the developer dose not play a main role in pattern formation.

At present, the pattern dimension of semiconductor integrated circuit approaches below a hundred nanometer level with being miniaturization, weight saving, and high efficiency of electronics devices, and narrowing of pattern width is proceeding in line with the loadmap. Therefore, the studies for pursuing high sensitivity and resolution of the photoresists for semiconductor integrated circuit have been actively run. On the other hand, the resolution of photoresists needed for producing printed wiring board and surface mount technology is not very high $(10-100 \mu \mathrm{m})$, but the resist films are require to have good mechanical and thermal properties because of permanent remaining of the films in the manufactures. Thus, polyimides, or polyamic acids as their precursors, have been usually used as polymers for such purposes. ${ }^{4}$ However, functional groups for affording photosensitivity must be introduced into the polymers, and the introduction of such functional groups brings about problems such as increased difficulty in the synthesis of photosensitive polyimides (PSPIs) and decreased physical and mechanical properties of the resulting PSPIs. When the polyamic acids were used, the problems like deformation of the patterns during thermal imidization often occur.

Recently, we have reported a novel pattern-forming process -reaction development patterning (RDP)-. ${ }^{5}$ One of the largest differences between RDP and the previously established processes is that chemical reaction between the developer and the polymers in development process is the main factor for pattern formation in RDP; the molecular weight of the polymers having carboxylic-acid-derivative $(-\mathrm{C}(\mathrm{O})-\mathrm{X}-)$ linkages decreases in exposed areas by nucleophilic acyl substitution of $-\mathrm{C}(\mathrm{O})-\mathrm{X}$ - with amine in the developer, and positive-tone patterns are formed by dissolution of the resulting low molecular weight compounds into the developer. Formation of carboxylic acid from photo-rearrangement reaction of the DNQ compound as photosensitive agent is used for preferential infiltration of the developer into exposed areas. One of the characteristics of RDP is that, in principle, every polymer can be used as photosensitive polymer when it has functional groups for reacting with nucleophile in developer and the reaction products have solubility into the developer. We have examined application of

${ }^{\dagger}$ To whom correspondence should be addressed (Tel/Fax: +81-45-339-3961, E-mail: oyama1@ynu.ac.jp). 
RDP for commercially available engineering plastics having $-\mathrm{C}(\mathrm{O})-\mathrm{X}$ - linkages in the main chain such as polyetherimide (PEI), ${ }^{6}$ polyarylate $(\mathrm{PAr}),{ }^{7}$ and polycarbonate $(\mathrm{PC}){ }^{8}$ In consequence, these novel photosensitive engineering plastics showed clear and sharp line/space $(\mathrm{L} / \mathrm{S})$ patterns at $\sim 10 \mu \mathrm{m}$ resolution. However, ultrasonic treatment was required for the development of PEI and PAr, and adhesion of PC to the substrate was poor. As a result of such the problems, application of RDP to practical processes is not still accomplished. Thus, a novel design of an engineering plastic suitable for application of RDP is strongly required.

In this study, we have chosen polyesterimides (PEsIs) as the engineering plastics because they are expected to be good solubility with keeping the desirable properties of polyimide. A variety of PEsI is easily prepared by reacting a diamine with various bis(esteranhydride)s and the relationship between structure of the polymers and lithographic properties in RDP is studied. As a result of these studies, the polymer structures suitable for RDP are examined.

\section{EXPERIMENTAL}

\section{Materials}

Bis[4-(3-aminophenoxy)phenyl]sulfone ( $m$-BAPS) (Wakayama Seika Kogyo Co., Ltd.) were used without further purification. 1,2-Bistrimellitoxyethane dianhydride (ME) was provided from Shin Nihon Rika Co., Ltd. 1,2-Naphthoqiunonediazide-5-sulfonic acid $p$-cresol ester $\left(\mathrm{PC}-5^{\circledR}\right)$ (Scheme 1) was purchased from Toyo Gosei Kogyo Co., Ltd. Other reagents and solvents were commercially available. Benzene,

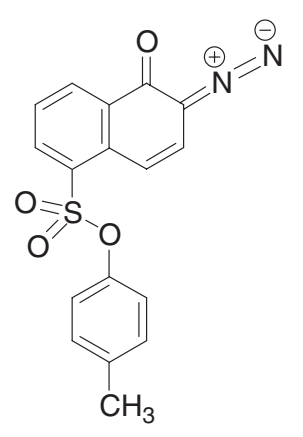

Scheme 1. 1,2-dichloroethane, and diethyl ether were distilled form sodium, and acetone and pyridine were distilled from calcium hydride.

\section{Measurement}

The molecular weight of PEsIs was determined using GPC (TOSOH TSK gel $\mathrm{GMH}_{\mathrm{HR}}-\mathrm{M}$ column, eluting rate $1.0 \mathrm{~mL} / \mathrm{min}$ ) equipped with $\mathrm{UV}$ detector (TOSOH, UV-8020) at room temperature using polystyrene standards and its mobile phase was DMF containing $\mathrm{LiBr}(30 \mathrm{mmol} / \mathrm{L})$ and phosphoric acid (60 mmol/L). ${ }^{1} \mathrm{H}$ NMR spectra were recorded on a JEOL JNM-EX-270 spectrometer $(270 \mathrm{MHz})$ at room temperature or $60^{\circ} \mathrm{C}$ using DMSO- $d_{6}$ as a solvent and tetramethylsilane as the internal standard. The glass transition temperature $\left(T_{\mathrm{g}}\right)$ of PEsIs was determined as the onset temperature by differential scanning calorimetry (DSC) (Shimadzu, DSC-60) at a heating rate of $10^{\circ} \mathrm{C} / \mathrm{min}$ under nitrogen. Thermogravimetric analyses (TGA) were carried out on a Shimadzu TGA-50 at a heating rate of $10^{\circ} \mathrm{C} / \mathrm{min}$ under nitrogen. Film thickness was measured with a contact-type thickness analyzer (Nikon, DIGIMICRO MFC-101). Irradiation was conducted by UV exposure apparatus (ORC, JP-2000-EXC), and the exposure dose was measured in the wavelength of $320-390 \mathrm{~nm}$ (ORC, UV-331AP2). Scanning electron micrographs (SEMs) were taken with a HITACHI S-2600N instrument.

\section{Monomer Synthesis}

Dianhydride monomers containing ester group, except for ME, were synthesized from trimellitic anhydride chloride (TMAC) and variant diols (Scheme 2). ${ }^{9-12}$

\section{Preparation of 2,2-Bis( p-trimellitoxyphenyl)propane dianhydride $(\boldsymbol{P})^{9}$}

TMAC $(42.11 \mathrm{~g}, 0.2 \mathrm{~mol})$, pyridine $(23.73 \mathrm{~g}, 0.3$ $\mathrm{mol})$, and benzene $(130 \mathrm{~g})$ were placed in a $300 \mathrm{~mL}$ three-necked flask fitted with a mechanical stirrer, a reflux condenser protected with a drying tube, and a powder addition funnel. Bisphenol A $(22.83 \mathrm{~g}$, $0.1 \mathrm{~mol}$ ) was added to the mixture portionwise over a period of $0.5 \mathrm{~h}$. The mixture was stirred under reflux for $3 \mathrm{~h}$, and finally allowed to cool to room temperature. Pyridine hydrochloride was removed by filtration and the filtrate was poured into in $2.0 \mathrm{~L}$ of hexane. The
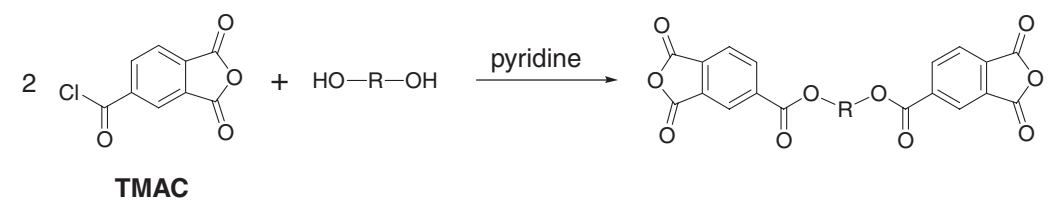

Scheme 2. 


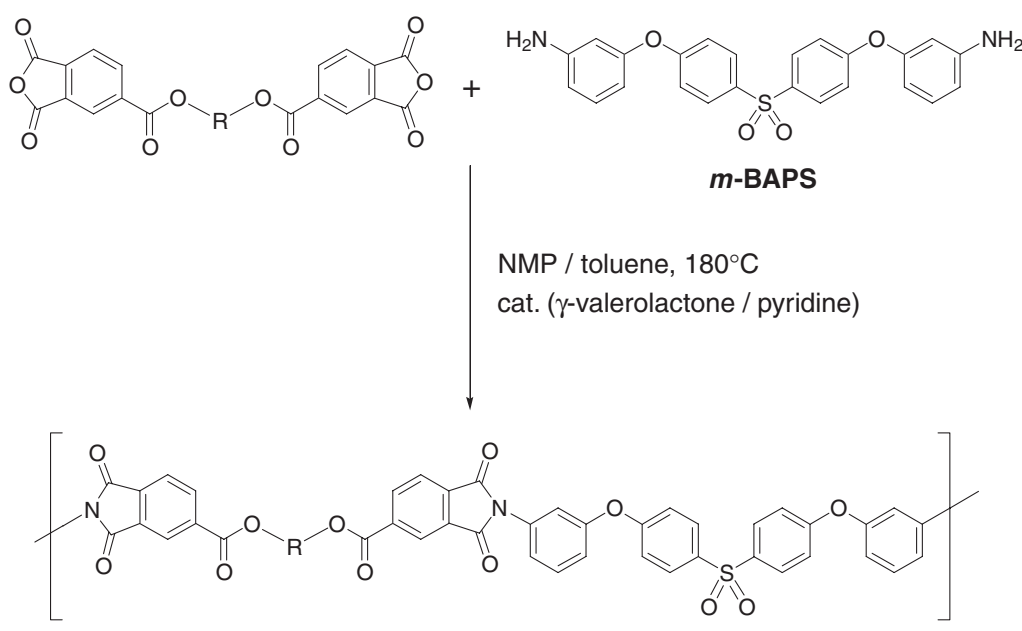

Scheme 3.

precipitate collected by filtration was dried at $60^{\circ} \mathrm{C}$ in vacuo to afford crude product of $\mathbf{P}$ in $85 \%$ yield (49.00 g).

The crude product $(28.82 \mathrm{~g}, 0.05 \mathrm{~mol})$, acetic anhydride $(20.42 \mathrm{~g}, 0.2 \mathrm{~mol})$, and benzene $(45 \mathrm{~g})$ were placed in a $300 \mathrm{~mL}$ three-necked flask fitted with a mechanical stirrer and a reflux condenser. The mixture was stirred under reflux for $1 \mathrm{~h}$, and finally allowed to cool to room temperature. The resultant mixture was poured into $2.0 \mathrm{~L}$ of hexane. The precipitate collected by filtration was dried at $150^{\circ} \mathrm{C}$ in vacuo to afford $\mathbf{P}$ in $62 \%$ yield $(17.89 \mathrm{~g})$.

\section{Polymer Synthesis}

Variant PEsIs were prepared using a similar procedure as previously reported method by a direct one-pot polycondensation of the dianhydrides and diamine in the presence of $\gamma$-valerolactone/pyridine catalyst using NMP/toluene mixture as a solvent (Scheme 3). ${ }^{13}$ Toluene was used for distilling water generated during cyclodehydration of the precursor polyamic acid away from the reaction system.

\section{Preparation of PESI-P}

The dianhydride monomer $\mathbf{P}(17.28 \mathrm{~g}, 30 \mathrm{mmol})$ and the diamine monomer $m$-BAPS $(12.98 \mathrm{~g}, 30$ $\mathrm{mmol}$ ) were placed in a $500 \mathrm{~mL}$ separable four-necked flask fitted with a Dean-Stark trap, nitrogen gas inlet, and a stainless steel anchor agitator. Then the mixture was dissolved in mixed solvent of NMP/toluene $(146 \mathrm{~mL} / 40 \mathrm{~mL})$, followed by the addition of $\gamma$ valerolactone $(0.30 \mathrm{~g}, 3.0 \mathrm{mmol})$ and pyridine $(0.47 \mathrm{~g}$, $6.0 \mathrm{mmol})$. The solution was heated at $180^{\circ} \mathrm{C}$ for $6 \mathrm{~h}$ with stirring $(180 \mathrm{rpm})$ and introducing nitrogen into the flask $(20 \mathrm{~L} / \mathrm{min})$. The resultant mixture was poured into $2.0 \mathrm{~L}$ of methanol, and the obtained precipitate was dissolved in NMP and reprecipitated in $2.0 \mathrm{~L}$ of methanol. The precipitate collected by filtration was dried at $60{ }^{\circ} \mathrm{C}$ in vacuo to afford PEsI-P in $96 \%$ yield $(28.00 \mathrm{~g})$.

\section{Preparation of Polyesterimide Films Containing a Photosensitive Agent}

20-30 wt \% of a PEsIs were dissolved in NMP. The DNQ compound PC- $5^{\circledR}$ as a photosensitive agent ( $30 \mathrm{wt} \%$ for PEsI) was dissolved in the NMP solutions. The resulting photosensitive PEsI solutions were degassed and spin-coated onto a shiny side of copper foil, and the photosensitive PEsI films with $\sim 15 \mu \mathrm{m}$ in thickness were obtained after prebaking at $90^{\circ} \mathrm{C}$ for $15 \mathrm{~min}$ in a far-infrared oven.

\section{Irradiation and Development}

The films were irradiated with an ultrahigh-pressure mercury lamp without any filter $\left(2000 \mathrm{~mJ} / \mathrm{cm}^{2}\right)$ at both the $i$ line and $g$ line through a positive photomask in a contact technique. The exposed films were developed in a mixture of ethanolamine $/ \mathrm{NMP} / \mathrm{H}_{2} \mathrm{O}$ at room temperature or $40^{\circ} \mathrm{C}$ under ultrasonication or by dipping, and rinsed with pure water.

\section{RESULTS AND DISCUSSION}

\section{Monomer Synthesis}

TMAC and diols were used for preparation of bis(esteranhydride) monomers because TMAC was inexpensive and various aromatic and aliphatic diols were available (Scheme 2).$^{9-12}$ The reaction of an acid chloride with a diol requires the presence of $\mathrm{HCl}$ accepter such as pyridine. The results of the dianhydride monomer synthesis are shown in Table I, and all the dianhydride monomers were prepared in good yield. The dianhydride monomers used in this study are shown in Scheme 4. ME, K2, and $\mathbf{S 2}$ are commercially available monomers, and $\mathbf{K} \mathbf{2}$ and $\mathbf{S 2}$ were used for copolymerization. 
Table I. Synthesis of dianhydride monomers

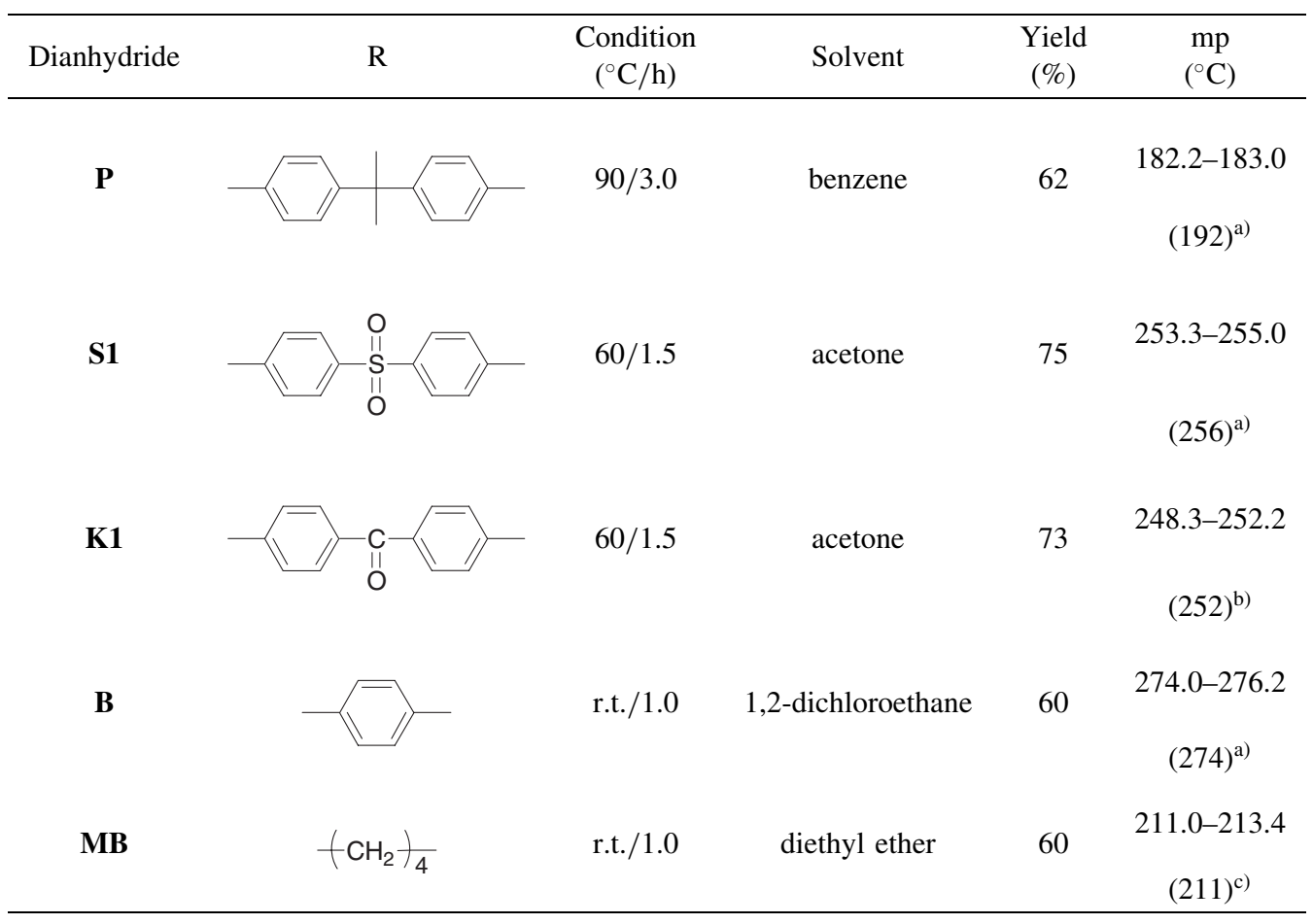

a) ref. 9, b) ref. 11, c) ref. 12 .<smiles>COC1C(=O)OC(=O)c2cc(OC(=O)c3ccc(C(C)(C)c4ccc(C(=O)Oc5ccc(C(C)(C)P)cc5)cc4)cc3)ccc21</smiles><smiles>CCCOC(=O)c1ccc2c(c1)C(=O)OC2=O</smiles><smiles>CCOC(=O)c1ccc(C(=O)Oc2ccc(S(=O)(=O)c3ccc(OC(=O)c4ccc5c(c4)C(=O)OC5=O)cc3)cc2)cc1</smiles>

S1<smiles></smiles>

K1<smiles></smiles>

MB<smiles>O=C(c1ccc2c(c1)C(=O)OC2=O)c1ccc2c(c1)C(=O)OC2=O</smiles>

K2<smiles></smiles><smiles>O=C1OC(=O)c2cc(S(=O)(=O)c3ccc4c(c3)C(=O)OC4=O)ccc21</smiles>

Scheme 4 .

Polymer Synthesis

To examine relationship between polymer structure and photosensitivity in RDP, PEsIs with various main chain structures were prepared by one-pot polycondensation between a diamine and the dianhydrides with ester group (Scheme 3). ${ }^{13}$ Copolyesterimides were also prepared to control the ratio of electronwithdrawing group in PEsIs. $m$-BAPS was selected as a diamine monomer because of good solubility of the resultant PEsIs. The results of the polymerization are shown in Table II. In the polymerizations, the water generated by the condensation was distilled with toluene out of reaction system. In theory, molecular weight for polycondensation of reversible reaction should gradually increase with reaction time. However, in the synthesis of PEsIs containing ketone 
Positive Photosensitive Polyesterimide

Table II. Synthesis of polyesterimides by polycondensation

\begin{tabular}{|c|c|c|c|c|c|c|c|c|c|c|}
\hline Entry & $\begin{array}{c}\text { Dianhydride(s) } \\
\text { (Molar ratio) }\end{array}$ & $\begin{array}{l}\text { Condition }^{\text {b) }} \\
\text { (h) }\end{array}$ & Polyesterimide & $\begin{array}{c}\text { Yield } \\
(\%)\end{array}$ & $\begin{array}{c}\text { Imidization ratio }^{\mathrm{c})} \\
(\%)\end{array}$ & $\begin{array}{c}M_{\mathrm{n}}^{\mathrm{d})} \\
\left(\times 10^{4}\right)\end{array}$ & $\begin{array}{c}M_{\mathrm{w}}{ }^{\mathrm{d})} \\
\left(\times 10^{4}\right)\end{array}$ & $M_{\mathrm{w}} / M_{\mathrm{n}}^{\mathrm{d})}$ & $\begin{array}{l}\left.T_{\mathrm{g}} \mathrm{e}\right) \\
\left({ }^{\circ} \mathrm{C}\right)\end{array}$ & $\begin{array}{l}T_{\mathrm{d} 5}{ }^{\mathrm{f})} \\
\left({ }^{\circ} \mathrm{C}\right)\end{array}$ \\
\hline 1 & $P$ & 6.0 & PEsI-P & 96 & $\sim 100$ & 1.9 & 4.2 & 2.2 & 202 & 446 \\
\hline 2 & $P$ & 6.0 & PEsI-PL & 93 & $\sim 100$ & 1.2 & 2.3 & 1.9 & 200 & 439 \\
\hline 3 & B & 3.0 & PEsI-B & 95 & $\sim 100$ & 3.4 & 5.4 & 1.6 & 207 & 477 \\
\hline 4 & M1 & 6.0 & PEsI-ME & 97 & $\sim 100$ & 1.8 & 3.8 & 2.1 & 177 & 420 \\
\hline 5 & M2 & 6.0 & PEsI-MB & 93 & $\sim 100$ & 2.1 & 5.4 & 2.4 & 157 & 368 \\
\hline 6 & K1 & 1.5 & PEsI-K & 93 & $\sim 100$ & 1.3 & 1.7 & 1.3 & 175 & 446 \\
\hline 7 & $\mathrm{~K} 1 / \mathrm{P}(1 / 1)$ & 1.5 & PEsI-KP1 & 99 & $\sim 100$ & 1.4 & 3.4 & 2.5 & 208 & 406 \\
\hline 8 & $\mathrm{~K} 1 / \mathrm{P}(1 / 2)$ & 1.5 & PEsI-KP2 & 96 & $\sim 100$ & 1.4 & 4.2 & 2.9 & 206 & 412 \\
\hline 9 & $\mathrm{~K} 1 / \mathrm{P}(1 / 4)$ & 1.5 & PEsI-KP4 & 94 & $\sim 100$ & 1.2 & 3.2 & 2.8 & 200 & 422 \\
\hline 10 & $\mathrm{~K} 1 / \mathrm{P}(1 / 19)$ & 1.5 & PEsI-KP19 & 95 & $\sim 100$ & 1.1 & 3.2 & 2.8 & 199 & 458 \\
\hline 11 & $\mathrm{~K} 1 / \mathrm{K} 2(1 / 1)$ & 2.0 & PEsI-KK & 97 & $\sim 100$ & 1.0 & 1.7 & 1.8 & 189 & 448 \\
\hline 12 & & 1.5 & & 99 & $\sim 100$ & 1.0 & 1.5 & 1.5 & 222 & 432 \\
\hline 13 & S1 & 3.0 & PEsI-S & - & - & 0.6 & 0.9 & 1.5 & - & - \\
\hline 14 & & 5.0 & & - & - & 0.4 & 0.6 & 1.3 & - & - \\
\hline 15 & $\mathrm{~S} 1 / \mathrm{P}(1 / 1)$ & 1.5 & PEsI-SP1 & 97 & $\sim 100$ & 0.7 & 1.2 & 1.7 & 175 & 419 \\
\hline 16 & $\mathrm{~S} 1 / \mathrm{P}(1 / 2)$ & 1.5 & PEsI-SP2 & 93 & $\sim 100$ & 1.0 & 2.1 & 2.1 & 183 & 430 \\
\hline 17 & $\mathrm{~S} 1 / \mathrm{P}(1 / 4)$ & 1.5 & PEsI-SP4 & 94 & $\sim 100$ & 1.1 & 2.5 & 2.4 & 190 & 448 \\
\hline 18 & $\mathrm{~S} 1 / \mathrm{P}(1 / 19)$ & 1.5 & PEsI-SP19 & 94 & $\sim 100$ & 1.1 & 2.5 & 2.4 & 195 & 455 \\
\hline 19 & $\mathrm{~S} 1 / \mathrm{S} 2(1 / 1)$ & 2.0 & PEsI-SS & 96 & $\sim 100$ & 0.9 & 1.4 & 1.5 & 210 & 434 \\
\hline
\end{tabular}

a) See Scheme 4 , b) At $180^{\circ} \mathrm{C}$, c) Determined by ${ }^{1} \mathrm{H}$ NMR (DMSO- $d_{6}, 60^{\circ} \mathrm{C}$ ), d) Determined by GPC (solvent: DMF), e) Determined from onset in DSC, f) Determined from $5 \mathrm{wt} \%$ loss temperature in TGA.

and sulfone groups, increase in the molecular weight stopped at $1.5 \mathrm{~h}$ of reaction time, and the molecular weight decreased at larger reaction times (Table II, entries 12-14). These results would be caused by the reaction of ester linkage in PEsIs (or the precursor polyamic acids) with the diamine monomer and/or with water generated by condensation. Electron-withdrawing property of ketone and sulfone groups would promote this side reaction and decrease the molecular weight. Thus, for synthesis of PEsIs having electronwithdrawing groups, short reaction time $(1.5-2.0 \mathrm{~h})$ was used, and PEsIs of a certain level of molecular weight $\left(M_{\mathrm{n}} \approx 10,000\right)$ were obtained.

PEsIs prepared in this study was available as thermally stable materials since those $T_{\mathrm{g}} \mathrm{s}$ were high as shown in Table II. Even PEsI-MB containing tetramethylene group showed $T_{\mathrm{g}}$ of $157^{\circ} \mathrm{C}$ (entry 5). Table III shows the solubility of the PEsIs. The difference in solubility appeared at THF and $\mathrm{CHCl}_{3}$. To cite an instance, copolyesterimides prepared from $\mathbf{K} 1$ and $\mathbf{P}$ monomers (PEsI-KPs) showed increased solubility with decreasing the ratio of ketone group in the polymers. Similar tendency was also observed in the copolyesterimides from $\mathbf{S 1}$ and $\mathbf{P}$ (PEsI-SPs).

\section{Pattern Forming Mechanism}

We have chosen PC-5 ${ }^{\circledR}$ (Scheme 1) as the photosensitive agent because PC- $5^{\circledR}$ has one diazo group in one molecule and the amount of diazo group is easily estimated. Though, in a previous study, ${ }^{13}$ we al-
Table III. Solubility of the polyesterimides

\begin{tabular}{cccccc}
\hline Polyesterimide & NMP & DMF & THF & $\mathrm{CHCl}_{3}$ & DMSO \\
\hline PEsI-P & + & + & + & + & + \\
PEsI-B & + & + & - & - & + \\
PEsI-MB & + & + & - & + & + \\
PEsI-ME & + & + & - & + & + \\
PEsI-K & + & + & - & - & + \\
PEsI-KP1 & + & + & - & - & + \\
PEsI-KP2 & + & + & + & - & + \\
PEsI-KP4 & + & + & + & - & + \\
PEsI-KP19 & + & + & + & - & + \\
PEsI-KK & + & + & - & - & + \\
PEsI-S & + & + & - & - & + \\
PEsI-SP1 & + & + & + & - & + \\
PEsI-SP2 & + & + & + & - & + \\
PEsI-SP4 & + & + & + & - & + \\
PEsI-SP19 & + & + & + & - & + \\
PEsI-SS & + & + & - & - & + \\
\hline
\end{tabular}

+ : soluble, - : insoluble, examined at $25^{\circ} \mathrm{C}$.

so used NT-200 ${ }^{\circledR}$ having multiple diazo groups in a molecule as the photosensitive agent, identification of the number of diazo group per molecule is needed before use.

The pattern-forming mechanism for RDP is shown in Figure 1.,14 The process is based on the difference in the affinity for the developer between the exposed and unexposed regions. In the exposed regions, photosensitive agent DNQ in the film converts to indenecarboxylic acid via ketene by the photo-initiated rear- 
(a)

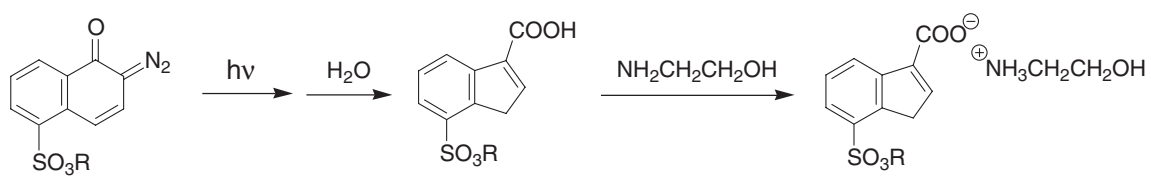

(b)

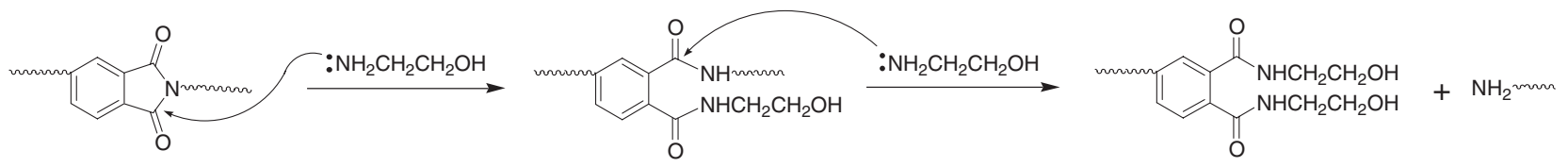

(c)

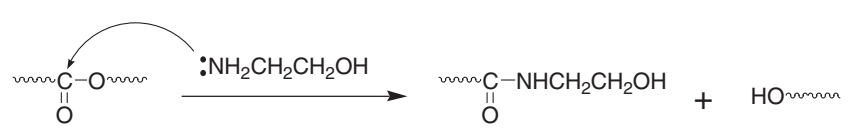

Figure 1. Mechanism of photosensitive PEsI system based on RDP. (a) Formation of indenecarboxylic acid by UV irradiation and formation of ammonium salt by the reaction of the acid with ethanolamine, (b) Reaction of imide ring with ethanolamine, and (c) Reaction of ester linkage with ethanolamine.

rangement. Reaction of the carboxylic acid and ethanolamine in the developer affords ammonium salt that promotes permeation of the hydrophilic developer into the exposed regions (Figure 1a). Then, molecular weight of the polymers at the exposed regions decreases by nucleophilic acyl substitution of the ethanolamine with $-\mathrm{C}(\mathrm{O})-\mathrm{X}-$, and the resulting lowmolecular-weight compounds are dissolved into the developer. When PEsIs are used as the polymers, there are two possibilities for reaction with ethanolamine, that is, reaction at imide ring (Figure 1b) and reaction at ester linkage (Figure 1c). On the other hand, in the unexposed regions, the hydrophilicity of the film does not increase because DNQ does not rearrange and cannot form ammonium salt with the amine in the developer. Thus, the difference in solubility to developer between the exposed and unexposed regions appears, and the patterns are formed. From the mechanism described above, it is considered that there are mainly two factors to decide the development property of photosensitive PEsI based on RDP, that is, (a) the permeability of the developer into the films and (b) the reactivity between ethanolamine and the ester linkage or the imide ring in PEsIs.

Development time of various PEsIs was compared in order to clarify the effect of polymer structure on development time (Table IV). The resist films containing DNQ compound (PC- $5^{\circledR}, 30 \mathrm{wt} \%$ for polymer) were irradiated $\left(2000 \mathrm{~mJ} / \mathrm{cm}^{2}\right)$ and then developed with a developer of ethanolamine/NMP/ $\mathrm{H}_{2} \mathrm{O}(4 / 1 / 1$ by weight) at $40{ }^{\circ} \mathrm{C}$ under dipping. The film thickness was unified into $15.0 \pm 0.5 \mu \mathrm{m}$ because the film thickness is an important parameter to decide development time. It is apparent that development time dramatically decreased by introducing electron-withdrawing
Table IV. Results of development for photosensitive PEsIs $\left.{ }^{\mathrm{a}) \mathrm{b}} \mathrm{c}\right)$

\begin{tabular}{ccc}
\hline Entry & PEsI & $\begin{array}{c}\text { Development time } \\
\left(\mathrm{min}^{\prime} \mathrm{sec}^{\prime \prime}\right)\end{array}$ \\
\hline 1 & PEsI-P & $120^{\prime} 00^{\prime \prime}$ \\
2 & PEsI-B & $4^{\prime} 17^{\prime \prime}$ \\
3 & PEsI-ME & $5^{\prime} 31^{\prime \prime}$ \\
4 & PEsI-MB & $4^{\prime} 00^{\prime \prime}$ \\
5 & PEsI-K & $3^{\prime} 12^{\prime \prime}$ \\
6 & PEsI-KP1 & $45^{\prime \prime}$ \\
7 & PEsI-KP2 & $1^{\prime} 05^{\prime \prime}$ \\
8 & PEsI-KP4 & $1^{\prime} 21^{\prime \prime}$ \\
9 & PEsI-KP19 & $1^{\prime} 47^{\prime \prime}$ \\
10 & PEsI-KK & $2^{\prime} 55^{\prime \prime}$ \\
11 & PEsI-S & $10^{\prime \prime}$ \\
12 & PEsI-SP1 & $1^{\prime} 25^{\prime \prime}$ \\
13 & PEsI-SP2 & $1^{\prime} 15^{\prime \prime}$ \\
14 & PEsI-SP4 & $1^{\prime} 10^{\prime \prime}$ \\
15 & PEsI-SP19 & $1^{\prime} 17^{\prime \prime}$ \\
16 & PEsI-SS & $2^{\prime} 32^{\prime \prime}$ \\
\hline
\end{tabular}

a) PEsI films containing $30 \mathrm{wt} \%$ of DNQ for polymers were used, b) Developed with a developer of ethanolamine/NMP/ $\mathrm{H}_{2} \mathrm{O}$ (4/1/1 by weight) at $40^{\circ} \mathrm{C}$ under dipping, c) Film thickness was $15.0 \pm 0.5 \mu \mathrm{m}$.

groups (Table IV, entries 5-16) compared to PEsI-P. This is due to uprising reactivity of carbonyl groups induced by the electron-withdrawing substituents. ${ }^{15}$ The results show that the nucleophilic attack of the ethanolamine in developer preferentially occurs at the ester linkages rather than imide ring, because the ester groups are closer and susceptible to the electron-withdrawing substituents than the imide rings. Though development times of PEsI-B, PEsI-ME, and PEsI-MB are expected to be the same level as that of PEsI-P, 


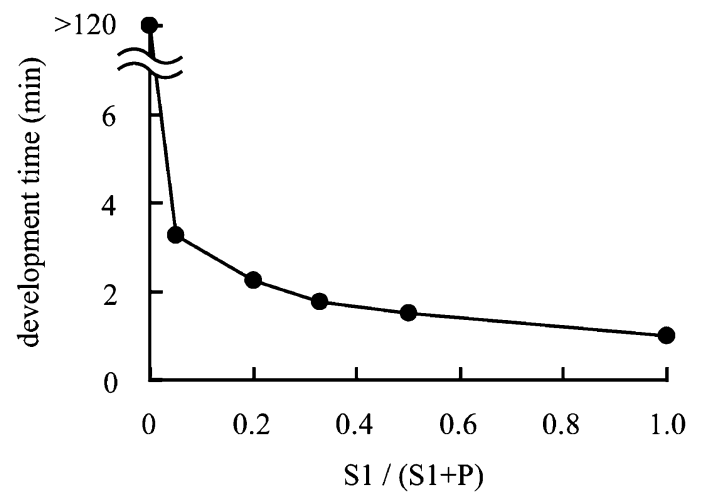

Figure 2. The relationship between the ratio of sulfone group in a copolymer and development time. Horizontal axis is the ratio of the unit $\mathrm{S} 1$ in a copolymer. The film was developed with ethanolamine $/ \mathrm{NMP} / \mathrm{H}_{2} \mathrm{O}(1 / 1 / 2$ by weight $)$ at $40^{\circ} \mathrm{C}$ under dipping. The film thickness was $15.0 \pm 0.5 \mu \mathrm{m}$.

their development times were much faster than that of PEsI-P. The results would be derived from the difference in permeability of the developer into the films due to difference in the structure of $\mathbf{R}$, that is, difference between aromatic and aliphatic groups as for PEsI-ME and PEsI-MB and difference in the amount of benzene ring as for PEsI-B. The relationship between development time and content of electronwithdrawing sulfone group in a polymer chain was investigated (Figure 2). The resist films with different amount of sulfone groups were developed with a developer of ethanolamine/NMP $/ \mathrm{H}_{2} \mathrm{O}(1 / 1 / 2$ by weight) until all the films were developed off. The results show that development time dramatically decreased by introducing just a little amount of sulfone group, and decreased with the increase of content of sulfone group. These results suggest that development property of PEsIs is easily adjusted by changing the ratio of electron-withdrawing groups in the polymers and that polymers with very short development time can be obtained by applying RDP to PEsIs.

\section{Lithographic Evaluation}

Photosensitive PEsIs were formulated with the same procedure as those for photosensitive polyimides $^{5}$ and polyarylates ${ }^{7}$ based on RDP, by dissolution of the polymers and a photosensitive DNQ compound PC- $5^{\circledR}$ (Scheme 1, $30 \mathrm{wt} \%$ of the polymer) in NMP. The lithographic potential of the photosensitive PEsI films were evaluated by irradiation of UV light through a photomask and subsequent development with ethanolamine $/ \mathrm{NMP} / \mathrm{H}_{2} \mathrm{O}$ developer at room temperature or $40^{\circ} \mathrm{C}$ under ultrasonication or dipping.

Figure 3 shows the sensitivity curve as a function of exposure dose for the photosensitive PEsI-P with $14.7 \mu \mathrm{m}$ in thickness. The sensitivity $\left(E_{0}\right)$ and slope of the curve $\left(\gamma\right.$ value) were about $850 \mathrm{~mJ} / \mathrm{cm}^{2}$ and

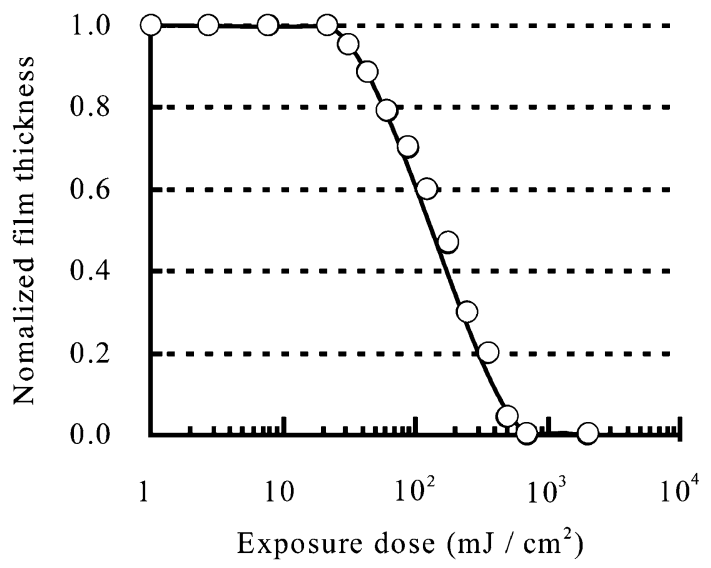

Figure 3. Sensitivity curve for photosensitive PEsI-P based on RDP. The film was developed with ethanolamine/NMP $/ \mathrm{H}_{2} \mathrm{O}$ (4/1/1 by weight) at $40^{\circ} \mathrm{C}$ under ultrasonication for $6 \mathrm{~min}$.

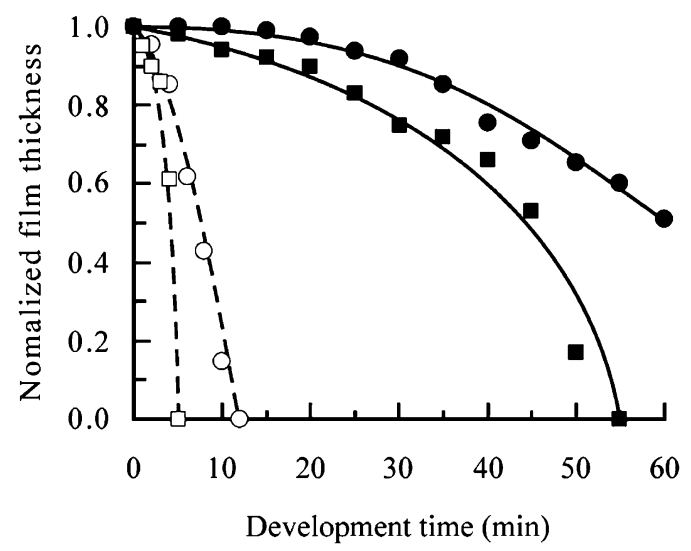

Figure 4. Dissolution curves of PEI $\left(\mathrm{Ultem}^{\circledR}, \bigcirc\right.$ : exposed regions, $\bullet$ : unexposed regions) and PEsI-P ( $\square$ : exposed regions, ఐ: unexposed regions) films. Both films were developed with ethanolamine/NMP $/ \mathrm{H}_{2} \mathrm{O}(4 / 1 / 1$ by weight $)$ at $40^{\circ} \mathrm{C}$ under ultrasonication.

0.8 , respectively. Value $E_{0}$ was estimated from the exposure dose where the resist film at the exposed area was completely dissolved into the developer.

Using PEsI-P and PEsI-PL (Table I, entries 1 and 2 ), the effect of the molecular weight of polymer on the development time was investigated. The development with ethanolamine/NMP/ $\mathrm{H}_{2} \mathrm{O}(4 / 1 / 1$ by weight) at $40^{\circ} \mathrm{C}$ under ultrasonication resulted in the development time of $6 \mathrm{~min} 5 \mathrm{~s}$ and $5 \mathrm{~min} 50 \mathrm{~s}$ for PEsI-P and PEsI-PL, respectively, and this imply that molecular weight of PEsIs has little or no influence on development behavior in this molecular weight level. Attempts to synthesize the polymers with higher molecular weight than PEsI-P were unsuccessful, probably due to degradation of the polymer main chain by the diamine monomer and/or water as mentioned in the polymer synthesis section.

Figure 4 shows the difference in dissolution rate be- 

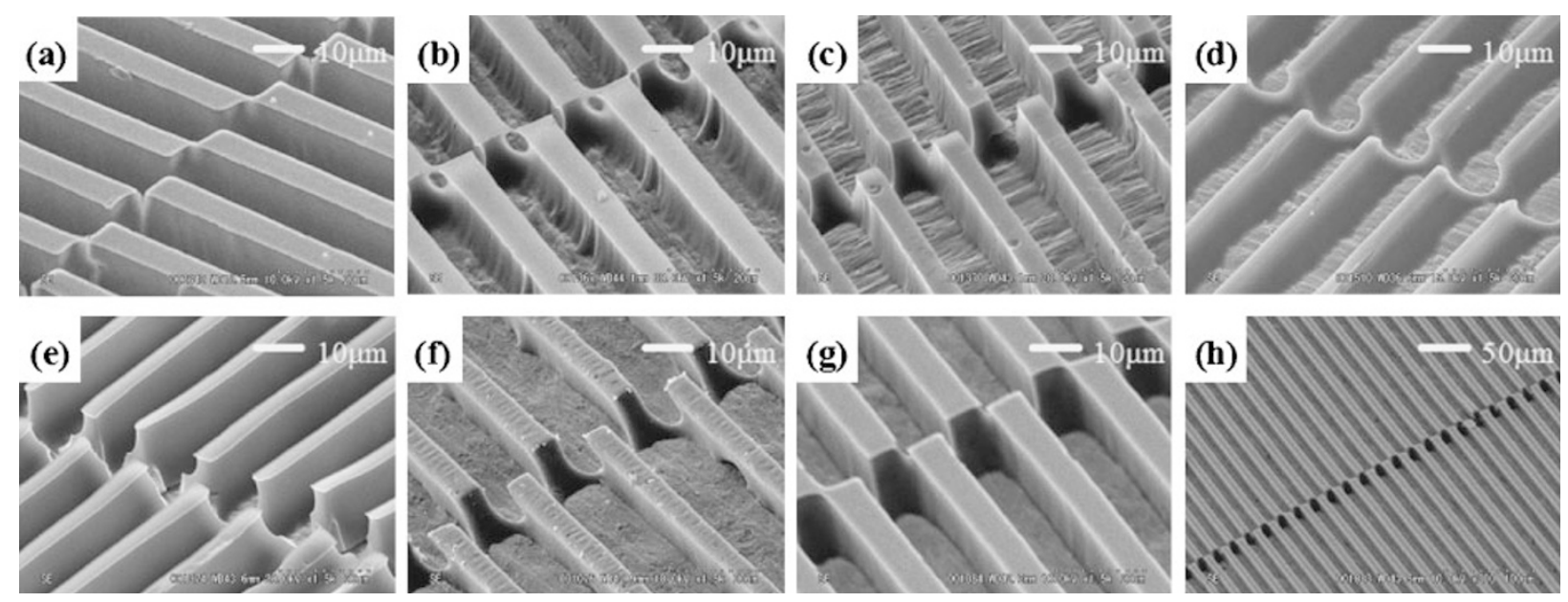

Figure 5. SEM images of $\mathrm{L} / \mathrm{S}$ patterns $(10 \mu \mathrm{m})$ for photosensitive PEsIs. (a) PEsI-P, developed with ethanolamine $/ \mathrm{NMP} / \mathrm{H}_{2} \mathrm{O}(4 / 1 / 1$ by weight) at $40^{\circ} \mathrm{C}$ under ultrasonication for $6 \mathrm{~min} 5 \mathrm{~s}$. (b) PEsI-B, developed with ethanolamine $/ \mathrm{NMP} / \mathrm{H}_{2} \mathrm{O}(1 / 2 / 4$ by weight $)$ at room temperature under dipping for $3 \mathrm{~min} 4 \mathrm{~s}$. (c) PEsI-SP2, developed with ethanolamine/NMP $/ \mathrm{H}_{2} \mathrm{O}(3 / 2 / 1$ by weight) at room temperature under dipping for $2 \mathrm{~min} 6 \mathrm{~s}$. (d) PEsI-S, developed with ethanolamine/NMP $/ \mathrm{H}_{2} \mathrm{O}(1 / 1 / 2$ by weight) at room temperature under dipping for 40 s. (e) PEsI-KP1, developed with ethanolamine/NMP $/ \mathrm{H}_{2} \mathrm{O}\left(1 / 2 / 4\right.$ by weight) at $40{ }^{\circ} \mathrm{C}$ under dipping for $3 \mathrm{~min} 4 \mathrm{~s}$. (f) PEsI-MB, developed with ethanolamine/ $\mathrm{NMP} / \mathrm{H}_{2} \mathrm{O}\left(6 / 4 / 3\right.$ by weight) at $40^{\circ} \mathrm{C}$ under dipping for $4 \mathrm{~min} 5 \mathrm{~s}$. (g) and (h) PEsI-SS, developed with ethanolamine/ $\mathrm{NMP} / \mathrm{H}_{2} \mathrm{O}\left(1 / 2 / 4\right.$ by weight) at $40^{\circ} \mathrm{C}$ under dipping for $3 \min 4 \mathrm{~s}$. (g) at magnification $1500 \times$, (h) at magnification $300 \times$.

tween the exposed and unexposed regions for PEsI-P and PEI $\left(\right.$ Ultem $\left.^{\circledR}\right)$. The dissolution times of the exposed regions are faster than those of unexposed regions at both PEI and PEsI systems, since the dissolutions in the exposed regions are accelerated by the formation of indenecarboxylic acid-ethanolamine salt. It is also clear from the figure that PEsI-P was dissolved faster than PEI at both the exposed and unexposed regions. This faster dissolution of PEsI-P would be attributed to the presence of the ester linkage, which has higher reactivity with ethanolamine than imide linkage. This result agrees with the results in Table IV and the discussion in the pattern forming mechanism section, that is, the development times of PEsIs are largely affected by the structural change in the vicinity of ester linkages. In both polymers, film thickness of the unexposed regions kept initial thickness when the exposed regions are completely dissolved. These results shown above indicate that the positive-tone pattern formation of photosensitive PEsIs based on RDP can be accomplished with faster development than PEI without dissolution at the unexposed regions.

Figure 5 shows SEM images of the representative L/S patterns of photosensitive PEsIs. The composition of the developers suitable for each PEsI was determined by changing three parameters of ethanolamine, NMP, and $\mathrm{H}_{2} \mathrm{O}$ based on the dissolution behavior shown in Table IV. In Figure 5a, clear and sharp L/S pattern of PEsI-P at $10 \mu \mathrm{m}$ dimensions was observed without any peeling off, swelling and deformation by the developer of ethanolamine/
$\mathrm{NMP} / \mathrm{H}_{2} \mathrm{O}$ (4/1/1 by weight). The $\mathrm{L} / \mathrm{S}$ patterns of PEsI-B were also formed by the same procedure as PEsI-P, while PEsI-B did not require ultrasonic treatment in development process. The $\mathrm{L} / \mathrm{S}$ patterns of PEsIs containing sulfone group often showed tapering forms, and the widths of space were larger than those of line (Figure $5 \mathrm{c}$ and $5 \mathrm{~d}$ ). When the patterns of PEsI-P, PEsI-SP2, and PEsI-S (Figure 5a, 5c, and 5d, respectively) were compared, it was observed that the lines were gradually thin down. These results suggest that the dissolution of the sulfone-containing PEsIs from side faces of the patterns was too fast and optimization of the development condition is difficult due to high reactivity of the ester linkages toward ethanolamine induced by the electron-withdrawing sulfone groups. In fact, for PEsIs with ketone group (PEsI-K, PEsI-KP1, PEsI-KP2, PEsI-KP4, and PEsI-KP19), the lines of L/S patterns were also slenderized. SEM image of PEsI-KP1 was shown in Figure 5e. However, the degree of pattern narrowing cannot be decided only by the content of electronwithdrawing group. For example, though narrowing of patterns for PEsI-MB are expected not to occur because the $\mathbf{R}$ of PEsI-MB is not electron-withdrawing group, the lines in the L/S patterns of PEsI-MB were thin down (Figure 5f). The results suggest that the degree of permeation of the developer from side face of the patterns, which also depends on the structure of the polymers, is another important factor for determining pattern shape. Finally, the L/S patterns of PEsISS are shown in Figure 5g and 5h. Clear and sharp $\mathrm{L} / \mathrm{S}$ patterns at $10 \mu \mathrm{m}$ dimensions were observed 
without any peeling off, swelling and deformation despite the presence of sulfone group. This would be due to the low content of ester linkage in PEsISS resulting from the use of both ester-containing and non-ester-containing monomers $\mathbf{S 1}$ and S2, respectively.

Thus, it is considered that the balance between the reactivity of ethanolamine with ester linkage and the permeability of the developer is important for the formation of the fine patterns, and it is suggested that adjustment of the amount of electron-withdrawing groups in a polymer by copolymeization can lead to fine patterns.

\section{CONCLUSION}

PEsIs with good thermal properties and solubility were prepared by one-pot polycondensation using catalysts of $\gamma$-valerolactone and pyridine. The photosensitive PEsI films showed positive patterns in the presence of DNQ by UV irradiation and the following development with the developer containing ethanolamine. The brilliant patterns were achieved by regulating the amount of electron-withdrawing group and ester group in the polymers. Development time also depends on the amount of electron-withdrawing group in the polymers, and the period needed for pattern formation decreased with increasing the ratio of the electron-withdrawing group. The preparation of the copolyesterimides containing electron-withdrawing group allowed improvement of lithographic property of the PEsI in RDP.

\section{REFERENCES}

1. "Polymers for Microelectronics," Y. Tabata, I. Mita, S. Nonogaki, K. Horie, and S. Tagawa, Ed., Kodansha, Tokyo, 1990.

2. R. Dammel, in "Diazonaphthoquinone-based Resists," The International Society for Optical Engineering, Washington, 1993.

3. H. Ito and W. C. Grant, Polym. Eng. Sci., 23, 1012 (1983).

4. N. Yoda and H. Hiramoto, J. Macromol. Sci., Part A: Pure Appl. Chem., 21, 1641 (2001).

5. T. Fukushima, T. Oyama, T. Iijima, M. Tomoi, and H. Itatani, J. Polym. Sci., Part A: Polym. Chem., 39, 3451 (2001).

6. T. Fukushima, Y. Kawakami, T. Oyama, and M. Tomoi, J. Photopolym. Sci. Technol., 15, 191 (2002).

7. T. Oyama, A. Kitamura, T. Fukushima, T. Iijima, and M. Tomoi, Macromol. Rapid Commun., 23, 104 (2002).

8. T. Oyama, Y. Kawakami, T. Iijima, and M. Tomoi, Polym. Bull., 47, 175 (2001).

9. D. F. Loncrini, J. Polym. Sci. Part A-1, 4, 1531 (1966).

10. J. E. Mulvaney, F. R. Figueroa, and S. J. Wu, J. Polym. Sci., Part A: Polym. Chem., 24, 613 (1986).

11. D. Sek, E. Schab-Balcerzak, and E. Grabiec, Polymer, 39, 7001 (1998).

12. B. N. Achar, G. M. Fohlen, and J. A. Parker, J. Polym. Mater., 2, 64 (1985).

13. T. Fukushima, K. Hosokawa, T. Oyama, T. Iijima, M. Tomoi, and H. Itatani, J. Polym. Sci., Part A: Polym. Chem., 39, 934 (2001).

14. T. Fukushima, Y. Kawakami, A. Kitamura, T. Oyama, and M. Tomoi, J. Microlith. Microfab. Microsyst., 3, 159 (2004).

15. T. Oyama, A. Kitamura, E. Sato, and M. Tomoi, J. Polym. Sci., Part A: Polym. Chem., 44, 2694 (2006). 